\title{
Including Estimates of the Future in Today's Financial Statements
}

\author{
Mary E. Barth \\ Graduate School of Business \\ Stanford University \\ and \\ International Accounting Standards Board
}

November 2005

I appreciate the helpful comments from Claudio Borio, Wayne Landsman, Jim Leisenring, Trish O’Malley, and participants in the Bank for International Settlements workshop on Accounting, Risk Management and Prudential Regulation. 


\section{Including Estimates of the Future in Today's Financial Statements}

\section{Introduction}

Almost all amounts recognized in financial statements today reflect some estimates of the future. Assets and liabilities, by definition, embody expected future inflows or outflows of economic benefits. Most measures of assets and liabilities incorporate estimates of the future. Thus, the question is not whether today's financial statements should reflect estimates of the future. Rather, it is how they should.

Regarding asset and liability measurement, International Financial Reporting Standards (IFRS) require many financial instruments to be measured at fair value and permit most others. Even though the use of fair values for measuring nonfinancial assets and liabilities is limited, the use of other measurement attributes that reflect estimates of the future is pervasive. Observation of the International Accounting Standards Board's (IASB) deliberations and review of its recent proposals reveals that the use of such estimates is likely to increase. The sources of the increase are more requirements to use current information when applying modified historical cost and broader use of fair value. This trend raises the question of which of these estimates should be included and how including more of them will affect financial statements.

The IASB's apparent focus on measuring assets and liabilities using more estimates of the future stems from its commitment to achieving the stated objective of financial reporting. In particular, the IASB Framework for the Preparation and Presentation of Financial Statements (Framework, IASCB, 1989) states that the objective of financial reporting is to provide information useful to financial statement users in making economic decisions. It seems self-evident that financial statement amounts that 
reflect current economic conditions and up-to-date expectations of the future will be more useful in making those decisions, which are made in the current economic environment. However, it also seems self-evident that not all expectations of the future should be recognized in financial statements today, particularly those that do not arise from events or transactions that have occurred.

The definitions of assets and liabilities also are critical for determining what types of expectations of the future are candidates for recognition in financial statements. One must identify precisely which asset or liability is being considered for recognition; different assets are associated with different expectations of the future. The present definitions depend critically on the identification of the past transaction or event that gives rise to the expected inflow or outflow of future economic benefits. The asset definition also requires that the entity control the resource. Thus, either only estimates of the future associated with past transactions or events under the control of the entity are to be considered, or standard setters need to change the definitions.

Income is the difference between net assets recognized at the beginning of the period and net assets recognized at the end of the period. Thus, how estimates of the future are incorporated into financial statements today affects the characteristics of income and its interpretation. For example, with more estimates of the future incorporated into today's measures of assets and liabilities, income will be less predictable. However, predictability of income itself is not an objective of financial reporting. Rather, it is income's predictive ability for future cash flows that is important. Including more current estimates of the future likely enhances income's predictive ability. 
This paper first explains why the question is how to incorporate estimates of the future in today's financial statements, not if. Second, it explains why selection of the measurement attribute for assets and liabilities affects how estimates of the future are incorporated into recognized amounts. It also explains why the IASB is focused on fair value as a measurement attribute. Third, it describes how the Framework definitions of assets and liabilities circumscribe the expected inflows and outflows of economic benefits that are candidates for financial statement recognition. These definitions play a critical role in limiting the types of future expectations that are included in financial statements. Fourth, it discusses the effects on income of incorporating more estimates of the future into today's financial statements. Finally, it offers some concluding remarks.

\section{Question is How, not If}

Including estimates of the future in today's financial statements is not new. Virtually all financial statement amounts today require estimates of the future. Cash in the entity's domestic currency is the exception. Accountants use accruals to adjust cash flows to reflect expectations of the future. For example, loans receivable reflects the amount that a bank expects to receive from its borrowers. The amount is determined by aggregating the contractually promised amounts and adjusting them for the time value of money and defaults expected based on current facts and circumstances. All of these assessments must be based on events that have occurred by the time the estimates are made. However, they all are estimates of the future, arising from those events. Thus, the question is not whether today's financial statements should incorporate estimates of the future. The question is how they should do so. 


\section{Which Measurement Attribute?}

How estimates of the future are incorporated in today’s financial statements depends on the attribute selected for asset and liability measurement. Each measurement attribute requires incorporating expectations with different characteristics. For example, fair value requires including expectations of future cash flows that market participants would include, discounted at the rate that marketplace participants would use to discount them. In contrast, entity-specific value requires including expectations of future cash flows that the entity expects to receive, discounted at a rate that reflects the entity's cost of capital, even if these differ from those of other entities.

\section{Multiple Measurement Attributes?}

Presently, financial statement amounts are based on a variety of measurement attributes. These include historical cost (used, e.g., for cash and held-to-maturity liabilities), modified historical cost (used, e.g., for property, plant, and equipment, and loans receivable), fair value (used, e.g., for derivatives and asset revaluations), and entityspecific value (used for, e.g., impaired inventories and impaired property, plant, and equipment). These differences in measurement attribute do not result from differences specified in the Framework. Rather, they result from conventions and differences in practice that have evolved over time. Thus, when viewed in terms of the Framework, these differences generate financial statements that are internally inconsistent.

Use of multiple measurement attributes not only is conceptually unappealing, but also creates difficulties for financial statement users. The amounts recognized in financial statements are combinations of amounts measured in various ways. This makes it difficult to interpret accounting summary amounts, such as net income. This difficulty 
is not limited to aggregated financial statement line item amounts. Sometimes individual items within a particular financial statement line item are recognized based on different measurement attributes, which are not disclosed. For example, an entity may state that it recognizes inventories at the lower of cost or net realizable value. However, it states this regardless of whether any inventory has been written down. Another example is an entity that recognizes an upward revaluation of property, plant, and equipment. Once the revaluation is recognized, it is difficult to determine which items of property, plant, and equipment and related depreciation the entity measures at cost and which it measures at fair value.

Using different measurement attributes also means that similar economic events could receive quite different accounting treatments. For example, presently contracts are recognized in financial statements differently, depending on the type of contract. If the contract is a lease, it either is not recognized on the balance sheet, if it is classified as an operating lease, or is capitalized, if it is classified as a financing lease. If the contract is a forward contract, it either is recognized at fair value, if it is classified as a derivative, or is not recognized, if it is not so classified. Yet, the economics of the two lease contracts or the two forward contracts are similar. Another example is if an entity asserts that it has the ability and intent to hold debt instruments to maturity, the instruments are recognized at historical cost. If the entity does not make the assertion, they are recognized at fair value. This, too, creates difficulties for users to understand financial statements that purport to reflect the economic activities of an entity. 
Why Fair Value?

Using a single measurement attribute could alleviate many of the difficulties associated with the present use multiple measurement attributes. Among the measurement attributes that have been considered for financial statements, the IASB seems focused on fair value. The IASB is focused on fair value because fair value accounting is the only comprehensive and internally consistent approach it has identified to improve financial reporting. ${ }^{1}$ It is not because the IASB advocates fair value per se; those concerned with using fair value have not offered a better alternative.

Using fair values to measure assets and liabilities is attractive because it meets many of the Framework's qualitative characteristics of useful financial statement information. These criteria are to be applied in the context of the primary objective of financial reporting, which is to aid investors and other users of financial statements in making economic decisions. ${ }^{2}$

The criteria include relevance, comparability, consistency, and timeliness. Fair values are relevant because they reflect present economic conditions, i.e., the conditions under which the users will make their decisions. Fair values are comparable because the fair value of any particular asset or liability is the same for every entity. It does not depend on which entity holds it or how or when it was acquired. Fair values enhance consistency because they reflect the same type of information in every period. Fair values are timely because they reflect changes in economic conditions when those conditions change. In addition, fair values can be viewed as fulfilling a stewardship role

\footnotetext{
${ }^{1}$ At the request of the IASB, the Canadian Accounting Standards Board has analyzed the characteristics of alternative measurement attributes. It has concluded that fair value should be the measurement attribute for initial recognition for all assets and liabilities.

${ }^{2}$ See Barth, Beaver, and Landsman (2001) for a summary of the empirical research relating to the value relevance of fair values.
} 
for financial reporting. This is because the financial statements reflect the values of assets at the entity’s disposal. Such values are essential for determining performance ratios such as return on capital employed. ${ }^{3}$

The hierarchy for estimating fair value in International Accounting Standard 39

Financial Instruments: Recognition and Measurement (IAS 39, IASB, 2004c) states that a market price is the best estimate of fair value. ${ }^{4}$ This is because a market price meets the definition of fair value. That is, it is the price that would obtain in an arms' length transaction between willing buyers and sellers. A market price does not include any entity-specific value that differs from the amount that other entities can realize. However, one must ensure that the asset or liability traded in the market is the same asset or liability whose fair value one seeks to obtain. If it is not, adjustments need to be made. For example, in the case of a portfolio of bank deposits, as discussed below, one needs to take into account that the price reflects the two components - the deposit liability and the value of expected future transactions. If the objective is to determine the fair value of the deposit liability alone, the observed price for a portfolio of deposit liabilities needs to be

\footnotetext{
${ }^{3}$ Paragraph 105 of Statement of Financial Accounting Standards (SFAS) No. 35, Accounting and Reporting by Defined Benefit Pension Plans, (Financial Accounting Standard Board, FASB, 1980b) states: The Board rejected using historical cost because prices in past exchanges do not provide the most relevant information about the present ability of the plan's assets to provide participants' benefits. Further, the Board does not believe that historical cost is the most appropriate measure for use in assessing how the stewardship responsibility for plan assets has been discharged. Plan administrators or other fiduciaries who manage plan assets are accountable not only for the custody and safekeeping of those assets but also for their efficient and profitable use in producing additional assets for use in paying benefits. Investment performance is an essential element of stewardship responsibility. Measuring changes in fair value provides information necessary for assessing annual investment performance and stewardship responsibility. Historical cost provides that information only when investments are sold. [Emphasis added].

In addition, paragraph 50 of Statement of Financial Accounting Concepts (SFAC) No. 1, Objectives of Financial Reporting by Business Enterprise, (FASB, 1978) discusses management's discharge of its stewardship responsibility as:

...not only for the custody and safekeeping of enterprise resources but also for their efficient and profitable use and for protecting them to the extent possible from unfavorable economic impacts of factors in the economy such as inflation or deflation and technological and social changes.

${ }^{4}$ The FASB has a similar hierarchy in its Fair Value Measurement Exposure Draft (FASB, 2004).
} 
adjusted. Finally, if the market is reasonably deep and liquid, then the market price is a reliable measure. ${ }^{5}$

\section{Which Assets and Liabilities?}

\section{Definitions of Assets and Liabilities}

The extent to which today's financial statements incorporate estimates of the future also depends on which assets and liabilities are recognized. This issue is broader than identifying the measurement attribute, none of which, including fair value, specify what is being measured. The IASB relies on the definitions of financial statement elements in the Framework to determine the entity's assets and liabilities:

An asset is a resource controlled by the entity as a result of past transactions and events and from which future economic benefits are expected to flow to the entity.

A liability is a present obligation of the entity arising from past events, the settlement of which is expected to result in an outflow from the entity of resources embodying economic benefits.

These definitions require that there be a past event or transaction that gives rise to a present right to future economic benefits controlled by the entity, or to a present obligation of the entity to transfer future economic benefits, i.e., an asset or liability. Importantly, these definitions identify what are the assets and liabilities of the entity and, thus, what expected future inflows or outflows of economic benefits are potential

\footnotetext{
${ }^{5}$ Reliability is a prominent concern with using fair values. The hierarchy in IAS 39 (IASB, 2004) attempts to address reliability concerns. As noted above, the hierarchy specifies that the best estimate of fair value is a market price. It specifies that the next best estimate is that obtained from valuation techniques that use market inputs. Estimates obtained from valuation techniques that use inputs that are not inconsistent with market characteristics also can be fair values, but should be used as a last resort. All of these are estimates of fair value. As the SFAC 7 points out (FASB, 2000, paragraph 68), a market price embodies the marketplace assessment of the present value of expected future cash flows. It does not represent a fundamentally different approach to estimating value. The FASB's Fair Value Measurement Exposure Draft (FASB, 2004) specifies how to calculate fair values, which is ongoing task of the IASB and the FASB.
} 
candidates for recognition in the financial statements. Recognition is a separate question that depends on other criteria. ${ }^{6}$

The Framework definitions of assets and liabilities make it clear that assets and liabilities embody expectations of the future. Thus, it is sensible that such expectations be reflected in the measurement of assets and liabilities. However, whether the entity has assets or liabilities is not based on expectations. This is because the definitions require assets and liabilities to be present rights or obligations. For assets, the definition also requires that the entity control the right. Thus, only estimates of future inflows of benefits that are associated with past transactions or events under the present control of the entity are recognized as assets. It is possible that standard setters should change the definition. $^{7}$ However, even with the present definitions, identifying the past transaction or event can require judgment and is open to debate, as is whether the asset control criterion is met.

\section{Past Transactions or Events}

Although the asset and liability definitions seem clear, there are legitimate questions as to which past transactions or events are appropriate to consider when determining which expected future inflows or outflows of economic benefits are considered assets and liabilities. Consider expected loan losses. IAS 39 requires banks to evaluate evidence of whether their loan assets are impaired (see IAS 39, paragraphs 58 through 62). IAS 39 states that there must be evidence that the event that affected the

\footnotetext{
${ }^{6}$ The Framework (paragraph 83) states that items that meet the definitions of assets and liabilities should be recognized "if: (a) it is probable that any future economic benefit associated with the item will flow to or from the entity; and (b) the item has a cost or value that can be measured with reliability.” For purposes of this paper, I assume all assets and liabilities that meet the Framework definitions also meet the recognition criteria.

${ }^{7}$ The IASB currently has a joint project with the FASB to complete, converge, and improve their conceptual frameworks. The project will revisit the definitions of assets and liabilities.
} 
entity's expectations of future cash flows has occurred. Consistent with the asset and liability definitions, it also states that "losses expected as a result of future events, no matter how likely, are not recognized.”

Identifying these events requires applying judgment, and IAS 39 contains several paragraphs to aid in that judgment. However, it does not specify when, precisely, the past ends and the future begins. For example, paragraph 59(a) indicates that significant financial difficulty of the borrower is evidence of impairment. But, significant financial difficulty could be established at different times. The borrower failing to make payments when due is evidence of impairment (see IAS 39, paragraph 59(b)). But, when did the financial difficulty begin? When the borrower's savings were depleted? When he lost his job, even though his savings account balance equaled several months of his income? When the factory at which he worked announced it planned to layoff a fraction of its workforce? When the demand for the factory's production declined? When the price of oil increased, thereby raising the price of the factory's output? This list is incomplete and IAS 39 (IASB, 2004) does not directly answer this question. Although the example relates to the measurement of an asset, not whether the asset definition is met, it points out some of the difficulty in determining past transactions or events. ${ }^{8}$ IAS 39 simply requires that there be objective evidence linking the past event to a reduction in present expectations of future cash inflows. That reduction in expected cash flows is a loss in the period because the expectation changed as a result of some event that occurred during the period.

\footnotetext{
${ }^{8}$ Note that the loan loss example is not about using fair value accounting. The issue of delineating the past and future arises whether the measurement attribute is fair value, entity-specific value, or any other attribute that requires assessing loan impairment - even current modified historical cost that is presently used for loan assets.
} 


\section{Which Asset?}

The identification of the asset or liability being accounted for is often a source of misunderstanding between the IASB and its constituents. Often discussion is framed as being about applying fair value accounting, when it is about defining the asset or liability. Some constituents seem to believe that if the entity has access to expected future net cash inflows, it has an asset. However, some inflows might derive from growth options available to the entity or expected profitable future transactions. As standard-setters analyze the situation, these inflows do not derive from past transactions or events and are not a present right controlled by the entity. Thus, they would not meet the definition of an asset. ${ }^{9}$ Only expected inflows that meet the asset definition can be considered for financial statement recognition. The same holds for liabilities.

As an example of this distinction, consider a bank's deposit liability. There is considerable controversy about what is the fair value of this liability. The IASB defines fair value as "the amount for which as asset could be exchanged, or a liability settled, between knowledgeable, willing parties in an arm's length transaction.” The liability in question is that to depositors. Some argue that the fair value of the liability is the amount payable by the bank on demand by the depositor. This is the liability's fair value because it is the price that a knowledgeable, willing buyer, e.g. another potential depositor, would pay the depositor to sell his deposit willingly. Why would such a buyer pay any more or any less? The deposit is effectively cash. This also is the price at which the transaction occurs between the bank and depositors.

\footnotetext{
${ }^{9}$ Growth options could arise from past transactions or events, such as a business combination. In that case, the fair value of the growth option is recognized as part of goodwill.
} 
Others argue that if the bank were to settle the liability willingly with another knowledgeable, willing bank, the acquiring bank would require less than the demand amount to assume the liability. Why is this? This is because depositors leave their funds on deposit for some period of time, and money has a time value. Determining the amount of the discount the acquiring bank would accept requires estimating how long the amount will be on deposit. This is where the implications of considering only past transactions come into play. In particular, the standard-setters view the past transaction to be the deposit of funds. Thus, the question is how long those funds will remain on deposit. This might not be a long period - perhaps a few weeks or months - which means that the discount would not be large. This is not to say that the depositor is not likely to deposit more funds to replace those he withdraws, and that the depositor will have an account balance for a longer period - perhaps years. However, these new deposits are the result of future transactions, not past transactions. Thus, the present liability definition would not include them. ${ }^{10}$

This analysis does not imply that the bank does not have expected net cash inflows associated with its relationship with its depositor. Therefore, it might have an asset. For example, it is possible that the bank expects the depositor to deposit replacement funds, resulting in a base level of a deposit liability that will not require cash outflows in the short-term. ${ }^{11}$ This possibility is validated when portfolios of deposits are traded between banks - the price is less than the demand amount. However, the analysis

\footnotetext{
${ }^{10}$ For a more complete description of the IASB's reasoning, see the Basis for Conclusions for IAS 39, paragraphs BC187 and BC188.

${ }^{11}$ As paragraph BC187(b) of the Basis for Conclusions for IAS 39 notes, the argument that would result in demand deposits being recognized at less than the demand amount because the bank expects a base level of deposit liability would also result in recognizing trade payables at below their face amount. As yet, there are no advocates of doing so.
} 
implies that this benefit arises from future transactions with the depositor, not from past transactions. Even if one could identify a past transaction, any potential inflows of economic benefits associated with those future transactions are not controlled by the entity. Thus, this potential inflow of economic benefits does not seem to meet the asset definition. The question of whether and how to account for this expected net cash inflow is separate from that of how to account for the deposit liability. That is, the analysis reveals that the price of a portfolio of demand deposits reflects at least two elements, the current deposit and the prospects for future deposits. ${ }^{12}$ The former meets the liability definition, but the latter might not meet the asset definition.

Next consider insurance contracts. Standard-setters view the past transaction to be the execution of the insurance contract. Because the contract gives the insurer control over cash inflows associated with the contract, the expected net cash inflows associated with the contract meet the definition of an asset. ${ }^{13}$ However, insurers expect many policyholders to renew their contracts when the contracts expire. This expectation is based on past experience that is likely to persist into the future. Thus, the question is whether the net asset associated with the initial insurance contract derives from the expected net cash inflows from the contractual terms of the initial contract alone, or does it include expected net cash inflows from expected subsequent contracts. As with the bank deposit liability example, the expected contract renewals could be considered

\footnotetext{
${ }^{12}$ This discussion characterizes the difference as a "which asset" question. Others would characterize it as a "which market" question. That is, in estimating fair value should one look to the bank-to-depositor market or bank-to-bank market? In most cases, as in the current example, changing the market effectively also changes the asset or liability.

${ }^{13}$ There also is a liability for the insurer's commitments under the contract and the analysis should proceed separately for any contractual assets and liabilities. For the purpose of this discussion, I refer only to the insurer as having a net asset.
} 
expected future transactions, not past transactions, that are not controlled by the entity. Thus, they might not meet the definition of an asset.

\section{Expected Future Transactions}

The asset (liability) definition does not state that any source of value (negative value) assessed by willing buyers and sellers of the entity's equity is an asset (a liability) of the entity. Thus, it is likely that some of the value of the firm's equity does not derive from the entity's assets and liabilities as defined in the Framework. As a consequence, that value is not recognized in the entity's financial statements. Such value sources could include expected cash inflows or outflows from expected future transactions or expected cash inflows that the entity does not control.

If one wishes to conclude that these expected future transactions are assets or liabilities, there are at least three possible alternatives. The first alternative is a fuller analysis that reveals that these expected transactions are, in effect, the result of past transactions. This would be the case, for example, if one concluded that the expected future deposits or insurance contract renewals resulted from establishing the initial depositor or policyholder relationship. The past event would not be the initial deposit or the execution of the contract. It would be the establishment of the customer relationship. Although this approach would include more expectations of the future in today's financial statements, it would not include them all. For example, it would not include expected net inflows from future depositors or policyholders. However, there is no reason for this line of reasoning to stop at the establishment of the customer relationship. That is, for example, one could conclude that the advertising that might result in a deposit or insurance contract is the past event. However, this first alternative would also have to 
deal with the control criterion in the asset definition. This is because concluding that these expected transactions are, in effect, the result of past transactions is not sufficient for them to meet the asset definition. One would also need to conclude that the associated expected future economic benefits are controlled by the entity. ${ }^{14}$

The second possible alternative is the development of new asset and liability definitions. Such revised definitions could include some or all expected future transactions that might not be controlled by the entity. If the notions of past transactions or events and control were eliminated from the asset definition, then it seems possible that all sources of equity value could be recognized in financial statements, assuming they meet the recognition criteria including reliable measurement. These sources could include real options, as well as the expected value of management's future decisions. ${ }^{15}$ One could envision what are presently considered as business risks to be recognized as liabilities. One also could envision expected future sales to be recognized as assets. This is a model for financial reporting very different from the one we have today. No standard setter has crafted such definitions as part of a comprehensive framework for financial reporting. Nonetheless, this alternative could result in many more estimates of the future being included in today's financial statements than would be the case using the current asset and liability definitions, even with full fair value accounting.

\footnotetext{
${ }^{14}$ It would be difficult to argue that the entity controls the depositor's future deposits or the insured's future insurance contract renewals. However, one might sustain an argument that the entity controls the economic benefits associated with such expected future transactions because it can sell the underlying deposits or contracts for a price that includes the value of those expected future transactions. Typically, when an asset or liability is acquired in an exchange transaction control is assumed. Such transactions also typically provide a reliable measure of the value of the asset or liability.

${ }^{15}$ The control criterion has been interpreted as eliminating from the asset definition the value of an assembled workforce. The argument is that entities do not control the expected future inflows of economic benefits associated with the efforts of their at-will employees because such employees can leave the entity's employ at any time.
} 
The third, perhaps most likely, alternative is that expected net cash inflows associated with expected future transactions would remain unrecognized. However, it is likely that the IASB will need to articulate more clearly what constitutes a past transaction or event, as well as control, and why. Expected Future Transactions and Reliability

Where we draw the line on past transactions or events also can affect the reliability of their measurement. ${ }^{16}$ This is because it usually is easier to estimate expected future cash flows associated with present rights and obligations than with expected future rights or obligations. ${ }^{17}$ For example, estimating expected future cash flows from expected future contracts requires estimating cash flows further into the future, which is inherently more difficult than estimating cash flows in the nearer-term. It also requires estimating the probability that a new contract will be entered into and the terms of that contract. Although some entities have considerable past experience on which to base such estimates, the estimates include an added level of estimation uncertainty. Also, these estimates necessarily rely more on management's plans, which also are inherently more subjective.

\footnotetext{
${ }^{16}$ Reliability of accounting amounts has several dimensions (FASB, 1980). One is verifiability, i.e., the extent to which different measurers would arrive at the same amount. This is the dimension most relevant here. Two other dimensions, neutrality, i.e., the amount is an unbiased measure of the object of measurement, and representational faithfulness, i.e., the extent to which the amount represents what it purports to represent, are assumed.

${ }^{17}$ If contracts trade, e.g., bank deposit liabilities, the resulting prices can provide a basis for a reliable estimate of the expected cash flows associated with expected future contracts. Thus, the conclusion as to whether the expected future net cash inflows are assets needs to rest on whether they meet the asset definition. Reliability only affects whether the asset should be recognized.
} 


\section{Effects on Income}

Income Measurement and Interpretation

The choice of which estimates of the future are reflected in today's financial statements affects how the financial statements should be interpreted. This is because the choice affects which expected future cash flows result in assets and liabilities and how the assets and liabilities are measured. Asset and liability measurement affects income measurement. As the Framework makes clear, the focus on measuring assets and liabilities is not because the IASB believes that the balance sheet is more important than the income statement. Quite to the contrary. It is because the income statement is important. The Framework adopts a Hicksian view of income (Hicks, 1946), adapted to financial reporting. The Hicksian view is that income for a particular period equals the change in wealth for that period. Thus, in a financial reporting context, the key to measuring income is to measure changes in recognized assets and liabilities (FASB and IASB, 2005). ${ }^{18}$

The direct link between asset and liability measurement and income measurement means that expectations of the future that are incorporated into measures of assets and liabilities today are recognized in income today, not in the future when the cash flows actually occur. Income in any given period includes changes in those expectations between the beginning and the end of the period, differences between the expectations

\footnotetext{
${ }^{18}$ Because not all assets and liabilities are recognized in financial statements, financial reporting does not literally implement the Hicksian view. Accounting income is not the change in total net assets for the period, it is the change in recognized net assets.
} 
and realizations during the period, and the unwinding of the discount rate. ${ }^{19}$ All realized cash flows are presented in the Statement of Cash Flows.

As discussed above, how estimates of the future are reflected in financial statements today depends on the choice of measurement attribute and the asset definition and its interpretation. Thus, both of these affect income and its interpretation. Generally stated, if used comprehensively, using fair value as the measurement attribute for assets and liabilities would result in income reflecting how the entity performed given the assets at its disposal relative to other market participants' expected performance. This is because fair value measures assets and liabilities based on what market participants expect an entity to be able to achieve. Thus, if the entity makes better use of the assets, income will be positive. If it makes worse use of the assets, income will be negative.

Using entity-specific value would reflect how the entity performed given its own plans and special rights or skills. This is because entity-specific value measures assets and liabilities based on what the entity expects to accomplish with the assets. Thus, the value of the entity's special rights or skills are recognized when the assets are recognized, not when the entity realizes the benefits associated with those special rights or skills. ${ }^{20}$ Using historical cost for all assets would reflect how the entity performed given the cost of its assets. Using a mixed measurement model, as we do presently, reflects a mixed view of entity performance, with unclear interpretation.

\footnotetext{
${ }^{19}$ The IASB's joint project with the FASB on Reporting Comprehensive Income is considering the best way to display income statement components, including these and those that result from the present mixed measurement model. As noted in footnote 5, market prices reflect market participants' assessments of expected cash flows and their risk. Thus, prices implicitly are the present value of expected future cash flows.

${ }^{20}$ There are likely few differences between fair value and entity-specific value for financial instruments. There could be larger differences for nonfinancial assets and liabilities.
} 
The balance sheet includes recognized amounts for individual assets and liabilities that, as explained above, do not necessarily reflect all sources of expected inflows or outflows of the entity's economic benefits. Thus, income in a given period also includes cash flows associated with unrecognized assets and liabilities, and unrecognized expected future transactions. A major class of unrecognized assets is internally generated intangible assets, even if they are contractual or otherwise separable from other assets of the entity, e.g., rights under a license agreement. Another major class of unrecognized assets is synergies between and among recognized assets.

The unit of account determines the extent to which synergies are recognized because any synergies within an asset’s unit of account are recognized. For example, any synergies obtained from combining metal, screws, tires, and a motor into an automobile are reflected in the recognized amount for the automobile. Also, consolidated balance sheets recognize the individual assets and liabilities of a subsidiary, which do not include synergies between and among those assets and liabilities. However, if balance sheets instead recognized the parent's investment in the subsidiary, the synergies at the subsidiary level would be reflected in the recognized amount. ${ }^{21}$

\section{Predictability}

One consequence of including more estimates of the future into today’s financial statements is that accounting income is less predictable. This follows because more expectations of the future are recognized in today's financial statements, leaving fewer to be recognized in future financial statements. If an entity could reliably predict the future, the predictions would be reflected in asset and liability measures today.

\footnotetext{
${ }^{21}$ This is the case in parent company separate financial statements prepared in accordance with IAS 27 (IASB, 2004a).
} 
Some view lack of predictability of accounting income as a drawback to incorporating more estimates of the future in today's financial statements, e.g., through the increased use of fair value accounting. However, the role of financial reporting is to provide information that is useful to users in making economic decisions. If next period's income is predictable from current period's income, then current period's income is predictable from last period's income. This means that users already have some of the information included in current period earnings, raising questions about what information current period's earnings provides. ${ }^{22}$ More importantly, the aim of financial reporting is to aid financial statement users in predicting future cash flows of the entity. Thus, what matters is whether accounting income has predictive ability with respect to future cash flows, not whether it is, itself, predictable. ${ }^{23}$

As explained above, income in any particular period would include differences between expectations and realizations, which are - by definition - unpredictable. Income also would include changes in expectations. The predictable part of income would be the return on the entity's net assets as reflected in the discount rate used, explicitly or implicitly in prices, to determine the present value of those expectations.

Although less predictable, income derived from assets and liabilities that incorporate more estimates of the future can provide information useful to financial statement users in making their economic decisions. The differences between expectations and realizations in any particular period, as well as changes in expectations

\footnotetext{
${ }^{22}$ Financial statements provide a confirmatory role as well as a predictive role. It is possible that current period's income provides confirmatory information even if it is predictable from last period's income. However, the criticisms of incorporating more estimates of the future into today's financial statements typically focus on income's lack of predictability, not its lack of confirmatory ability.

${ }^{23}$ Barth, Cram, and Nelson (2001) models and empirically demonstrates the significant relation between accounting income, and its components, and future cash flows.
} 
of the future, reveal changes in economic circumstances that occurred during the current

period. Because income also would include the expected return on the entity's net assets, aggregate income would reflect the extent to which the entity earned more or less than expected based on the riskiness of its net assets. ${ }^{24}$

\section{Disclosure as a Substitute?}

Recognition using fair values or other asset and liability measurement attributes that consider estimates of the future is one way to incorporate estimates of the future into today's financial statements. It is not the only way. Another is disclosure, for example, in notes to the financial statements. The Framework states that disclosure is not a substitute for recognition, but can be a complement.

Disclosures of expectations of the future can be of different types. ${ }^{25}$ One type is disclosures of an alternative asset or liability measure that could be recognized in the financial statements, but is based on more or different types of estimates of the future than the recognized amount. The present requirement in IAS 32 (IASB, 2004b) to disclose fair values of financial instruments that are recognized using another measurement attribute is an example. This type of disclosure provides measures of assets and liabilities that are useful to financial statement users, but for some reason not recognized. ${ }^{26}$

\footnotetext{
${ }^{24}$ If the measurement attribute is fair value, income reflects differences between what the entity earned from its net assets relative to what other market participants would have earned. Thus, any special management skill or other competitive advantages of the entity will be reflected in income as they manifest. ${ }^{25}$ See Barth and Murphy (1994) for an analysis of the different types of disclosures in U.S. accounting standards.

${ }^{26}$ Some reasons for this could be concerns over the reliability of the measures, unresolved interactions between the disclosed amounts and other recognized amounts, or a desire to increase preparers' and users' familiarity with the measures before requiring recognition. Barth, Beaver, and Landsman (1996) provide evidence that analogous disclosures required by SFAS 107 (FASB, 1995) are value relevant to investors in a sample of publicly traded U.S. banks, including fair values of banks' loan assets.
} 
A second type is disclosures of inputs to the estimation process. The present requirement in International Financial Reporting Standard (IFRS) 2 Share-based Payment (IASB, 2004d) to disclose expected volatility and other inputs to option-pricing models used to estimate the value of share options is an example. The inputs are estimates of the future. This type of disclosure provides information about how the entity incorporate estimates of the future in determining the asset and liability measures, and what those estimates are. This permits financial statement users to obtain a deeper understanding of the entity's expectations of the future, at a level that the users can relate the entity's estimates to other available benchmarks. This also helps users assess the reliability of the estimates. $^{27}$

A third type is disclosure of risk assessments. The present requirements in IFRS 7 (IASB, 2005) to disclose estimates of credit risk, liquidity risk, and market risk are an example. This type of disclosure provides financial statement users with information about the variance of the future expectations. The first two types of disclosures and recognized amounts relate only to the mean. Information about the variance of estimates of the future can be important to users in making their economic decisions. ${ }^{28}$

\section{Concluding Remarks}

Including estimates of the future in today's financial statements is not new almost all asset and liability amounts today reflect some estimates of the future. However, the use of such estimates is increasing. This increase results primarily from standard-setters' attempts to achieve the objective of financial reporting, which is to

\footnotetext{
${ }^{27}$ Aboody, Barth, and Kasznik (ABK, 2005) studies the disclosed inputs to option pricing models used to measure stock-based compensation expense under SFAS 123. ABK provides empirical evidence on the factors associated with the extent to which firms manage the inputs as a means of managing SFAS 123 expense.

${ }^{28}$ See Barth (2004) for a discussion of the potential usefulness of such disclosures.
} 
provide information useful to financial statement users in making economic decisions. Asset and liability measures that reflect current economic conditions and up-to-date expectations of the future should result in more useful information for making these decisions.

How estimates of the future are incorporated in today's financial statements depends in large part on the attribute selected for asset and liability measurement. Different measurement attributes result in different types of estimates being incorporated. It also depends on the definitions of assets and liabilities that are used for financial reporting. The present definitions depend critically on the identification of the past transaction or event that gives rise to expected inflows or outflows of future economic benefits. The asset definition also requires that the entity control the right associated with those expected benefits. Thus, some expected inflows and outflows economic benefits are not recognized.

Although recognized financial statement amounts may increasingly depend on estimates of the future, there is no present expectation that financial statements will reflect all such estimates. Thus, there is a role for note disclosures not only to explain the estimates that are included in recognized amounts, but also to provide information about estimates that are unrecognized.

How estimates of the future are incorporated into financial statements today affects the characteristics of income and, thus, its interpretation. Including more estimates of the future in today's financial statements would result in income that is somewhat different from income today. Arguably, the new income measure will provide better information to financial statement users in making their economic decisions. 


\section{References}

Aboody, D., M. E. Barth, and R. Kasznik. 2005. “Do Firms Manage Stock-Based Compensation Expense Disclosed under SFAS 123?” Working paper. Stanford University, Graduate School of Business.

Barth, M. E., 2004. "Fair Values and Financial Statement Volatility”, in The Market Discipline Across Countries and Industries, Edited by Claudio Borio, William Curt Hunter, George G. Kaufman, and Kostas Tsatsaronis (Cambridge, MA: MIT Press).

Barth, M. E., W. H. Beaver, and W. R. Landsman. 1996. "Value-Relevance of Banks' Fair Value Disclosures under SFAS 107.” The Accounting Review (October).

Barth, M. E., W. H. Beaver, and W. R. Landsman. 2001. “The Relevance of the Value Relevance Literature For Financial Accounting Standard Setting: Another View.” Journal of Accounting and Economics 31: 77-104.

Barth, M. E., D. P. Cram, and K. K. Nelson. 2001. “Accruals and the Prediction of Future Cash Flows,” The Accounting Review 76 (January): 27-58.

Barth, M. E., and C. M. Murphy. 1994. “Required Financial Statement Disclosures: Purposes, Subject, Number, and Trends” Accounting Horizons (December).

Hicks, J. R. 1946. Value and Capital. Second Edition (Oxford: Clarendon Press). Financial Accounting Standards Board. 1978. Statement of Financial Accounting Concepts No. 1: Objectives of Financial Reporting by Business Enterprises. Norwalk, CT.

Financial Accounting Standards Board. 1980a. Statement of Financial Accounting Concepts No. 2: Qualitative Characteristics of Accounting Information. Norwalk, CT. 
Financial Accounting Standards Board. 1980b. Statement of Financial Accounting

Standards No. 35: Accounting and Reporting by Defined Benefit Pension Plans. Norwalk, CT.

Financial Accounting Standards Board. 1995. Statement of Financial Accounting Standards No. 107, Accounting for Stock-based Compensation. Norwalk, CT. Financial Accounting Standards Board. 2000. Statement of Financial Accounting Concepts No. 7: Using Cash Flow Information and Present Value in Accounting Measurements. Norwalk, CT.

Financial Accounting Standards Board. 2004. Proposed Statement of Financial Accounting Standards: Fair Value Measurements. Norwalk, CT. Financial Accounting Standards Board and International Accounting Standards Board. 2005. Revisiting the Concepts. Norwalk, CT and London, UK.

International Accounting Standards Committee Board. 1989. Framework for the Preparation and Presentation of Financial Statements. London, UK.

International Accounting Standards Board. 2004a. International Accounting Standard 27 Consolidated and Separate Financial Statements. London, UK.

International Accounting Standards Board. 2004b. International Accounting Standard 32 Financial Instruments: Disclosure and Presentation. London, UK.

International Accounting Standards Board. 2004c. International Accounting Standard 39 Financial Instruments: Recognition and Measurement. London, UK.

International Accounting Standards Board. 2004d. International Financial Reporting Standard 2 Share-based Payment, London, UK. 
International Accounting Standards Board. 2005. International Financial Reporting Standard 7 Financial Instruments: Disclosures. London, UK. 